\title{
Cryopreservation in mammalian conservation biology: current applications and potential utility
}

This article was published in the following Dove Press journal:

Research and Reports in Biodiversity Studies

20 March 2015

Number of times this article has been viewed

\section{Alexandre Rodrigues Silva \\ Gabriela Liberalino Lima \\ Gislayne Christianne Xavier \\ Peixoto \\ Ana Liza Paz Souza \\ Laboratório de Conservação de Germoplasma Animal, Universidade Federal Rural do Semi-Árido (UFERSA), Mossoró, RN, Brazil}

Correspondence: Alexandre Rodrigues Silva

Laboratory of Animal Germplasm

Conservation, Universidade Federal Rural do Semi-Árido (UFERSA), BR I I0,

Km 47, Costa e Silva, Mossoró,

RN 59625-900, Brazil

$\mathrm{Tel} / \mathrm{Fax}+558433178374$

Email legio2000@yahoo.com

\begin{abstract}
A rapid and continuous decline in wild mammalian species populations has been documented in recent decades. Although in situ conservation strategies such as habitat preservation are usually the best way to preserve biodiversity, other rescue strategies such as germplasm cryopreservation are sometimes necessary. Germplasm cryopreservation involves the freezing of gametes, embryos, gonadal tissues, or somatic tissues of species threatened with extinction. There is substantial diversity in the cryobiological requirements among cell types and tissues of each species. Research has focused on adapting techniques developed for the conservation of the genetic material of domestic animals for use with wild species about which relatively little is known. This review describes and discusses the current and potential use of cryobanking for the preservation of cells and tissues of threatened species.
\end{abstract}

Keywords: cryobanking, gametes, somatic cells, germplasm preservation

\section{Introduction}

A rapid and continuous decline in wild mammalian species has been documented in the last decade, whereby one in every four mammalian species is threatened with extinction. ${ }^{1}$ Although in situ conservation strategies such as habitat preservation are usually the best way to preserve biodiversity, other rescue strategies such as germplasm cryopreservation are sometimes necessary to facilitate the natural processes of evolution to continue. ${ }^{2}$ However, this method alone is inefficient when a population is severely reduced or when the majority of remaining mammals are located in unprotected areas. ${ }^{3}$ As a result, there has been a rise in the number of ex situ conservation programs involving both in vivo and in vitro preservation, including the establishment of germplasm banks. ${ }^{4}$

Conservation of genetic resources focuses on the cryopreservation of gametes, embryos, gonadal tissues, and somatic tissues. ${ }^{2}$ Germplasm cryopreservation ${ }^{3}$ represents a connection between in situ and ex situ conservation programs. ${ }^{2}$ In the present review, we describe and discuss the current and potential uses of cryobanking of cells and tissues aimed at the prevention of the extinction of threatened mammalian species.

\section{The preservation of female gametes}

Female gametes (ova) can be obtained through follicle puncture, ovarian tissue biopsies, unilateral or bilateral ovariectomy, or ovary collection immediately after an animal's death, irrespective of its age. ${ }^{5}$ Ovarian tissue, isolated follicles, and mature or immature oocytes can all be stored by cryopreservation. ${ }^{6}$ The option of cryopreserving the 
ovarian tissue avoids many limitations encountered in mature oocyte preservation, such as the low number of mature oocytes available in the ovaries, possible deleterious effects of its conservation under low temperatures, and the need for super-ovulation procedure. ${ }^{7}$ The major limitation of its use is the difficulty in preserving ovarian tissue, given the diversity of cell types and tissue components. ${ }^{8}$

Oocyte preservation is more challenging, not least because oocytes tend to be large cells that have a low surface-to-volume ratio and a low permeability coefficient, both of which hinder the migration of water and cryoprotectants (CPAs) through the cell. ${ }^{9}$ Immature oocytes at the germinal vesicle stage that have not yet formed the spindle lack cortical granules and have a higher membrane permeability, making them more resistant to chilling injury than mature metaphase II oocytes. ${ }^{10}$ Two methods have been described for female gametes preservation: slow freezing (SF) and vitrification. SF or conventional freezing refers to the exposure of the tissues/cells to a low concentration of CPA and cooling them slowly in a programmable freezer. ${ }^{11}$ CPA concentration and exposure time prior to freezing needs to be balanced in order to reach sufficient dehydration; however, it has to be low enough to avoid cytotoxic damages. ${ }^{12}$ Although it is a widespread method, in general, sophisticated and expensive programmable freezers are required for the cooling procedure, but these freezing devices are not generally available when endangered animals are found dead on the field, making impossible the gamete preservation of wild animals in such conditions. ${ }^{7}$ On the other hand, vitrification is considered a cheap method that can be performed under field conditions with no need for special equipment, making it a good alternative for use in various settings often encountered with wildlife species, ${ }^{13}$ including after animal death. ${ }^{14}$ This method involves the use of high concentrations of CPAs and rapid cooling $\left(-20,000^{\circ} \mathrm{C} / \mathrm{min}-40,000^{\circ} \mathrm{C} / \mathrm{min}\right)$ to achieve a glass-like highly viscous solution without the formation of ice crystals. ${ }^{15}$ Vitrification promotes a viscosity state to the solution, but without water crystallization. ${ }^{16}$

In recent years, several studies have demonstrated the possibility of adapting the techniques developed for cryopreserving domestic female genetic material to wild species. The chilling of ovarian tissue has been efficiently demonstrated in kangaroos (Macropus giganteus ${ }^{17}$ ), red deer (Cervus elaphus hispanicus $^{18}$ ), and collared peccaries (Pecari tajacu $\left.{ }^{19}\right)$, in which ovarian tissue vitrification allowed the maintenance of the morphological integrity of more than $70 \%$ of the follicles after rewarming. ${ }^{20}$

Cryopreservation of the gametes of non-human primates has received a great deal of attention because these animals are used as experimental models for humans. In the baboon (Papio anubis), ovarian tissue vitrification followed by autografting resulted in follicle survival, growth, and ovulation (as indicated by the presence of corpora lutea). ${ }^{21}$ Similar results have been reported in cynomolgus monkeys (Macaca fascicularis) using both vitrification ${ }^{22}$ and SF followed by autografting. ${ }^{23}$ The birth of offspring from freshly grafted ovarian tissue was first described in rhesus monkeys (Macaca mulatta). ${ }^{24}$

Wiedemann et $\mathrm{al}^{25}$ reported the success of the SF method followed by the in vitro culture of ovarian tissue in the African lion (Panthera leo), Amur leopard (Panthera pardus orientalis), black-footed cat (Felis nigripes), oncilla (Leopardus tigrinus), Geoffroy's cat (Leopardus geoffroyi), Northern Chinese leopard (Panthera pardus japonensis), rusty-spotted cat (Prionailurus rubiginosus), serval (Leptailurus serval), and Sumatran tiger (Panthera tigris sumatrae). On the other hand, viable immature oocytes of wolves were obtained using the vitrification method. ${ }^{26}$

Studies carried out on carnivorous marsupials (Sminthopsis crassicaudata, Sminthopsis harrisi, Dasyurus viverrinus, and Dasyurus hallucatus) demonstrated that follicle viability could be maintained for 48 hours during ovarian tissue chilling using phosphate-buffered saline (PBS) as the base medium. In addition, almost $70 \%$ of isolated oocytes either survived vitrification ${ }^{27}$ or the preservation of ovarian fragments after vitrification. ${ }^{28}$

Conventional freezing of ovarian fragments maintained oocyte integrity in agoutis (Dasyprocta aguti ${ }^{29}$ ), African elephants (Loxodonta africana ${ }^{30}$ ), and wombats (Lasiorhinus $\left.k_{\text {refftii }}{ }^{3-33}\right)$, while vitrification of ovarian fragments maintained oocyte integrity in whales. ${ }^{34}$

In addition, the resumption of meiosis of isolated immature oocytes of Asian antelopes (Tetracerus quadricornis) after vitrification followed by in vitro maturation has been reported. ${ }^{35}$

\section{The preservation of male gametes}

Systematic cryopreservation and storage of male gametes from endangered species circumvents the problem of homozygosis in isolated populations by introducing new genetic material across populations and facilitates genetic exchanges between captive areas/zoos/research centers or countries. ${ }^{36} \mathrm{It}$ is possible to cryopreserve semen, epididymal spermatozoa, or spermatogonial stem cells that are either isolated or in testicular tissue. ${ }^{37}$ Each cell type has specific requirements during cryopreservation. Differences in the physical size and shape of spermatozoa may influence their susceptibility to thermal 
shock and resistance to osmotic stress during the freeze-thaw process when the stability of the membrane is challenged..$^{38}$ Furthermore, epididymal spermatozoa are not exposed to the complex secretions of the accessory sex glands, and this could alter both the sensitivity to chilling and the resistance to freezing of ejaculated spermatozoa. ${ }^{39}$

Electroejaculation is the most frequently used method for semen collection in wild species because it prevents manipulation risks during the procedure and requires chemical restraint of the animal. Other methods for semen collection include the use of internal artificial vaginas or vaginal condoms. ${ }^{40}$ In addition, post-coital sperm recovery has proved to be successful method of semen collection in marmoset monkeys ${ }^{41}$ and rhinoceros. ${ }^{42}$

The protocols used for cryomethods in the preservation of sperms of domestic animals have been adapted for use in wild species of interest. ${ }^{43}$ Protocols such as chilling allow sperm cell preservation for short periods of time, while freezing is used for longer periods. Semen cryopreservation is an established technique and differences in efficacy may be attributed to particularities of each species. ${ }^{4}$ In general, spermatozoa from most mammalian species have displayed good results after $\mathrm{SF}\left(-0.5^{\circ} \mathrm{C} / \mathrm{min}\right)$, recovering at least some motility after thawing. ${ }^{44}$ Tris and TES are among the most employed diluents used in semen preservation, ${ }^{45}$ while coconut water has been used in the capuchin monkey, ${ }^{46}$ the agouti, ${ }^{47}$ and the collared peccary. ${ }^{4}$ In addition, milk-based cryoextenders have also been used to successfully freeze the sperm from species such as the Asian elephant (Elephas maximus indicus $)^{48}$ and the Indian rhinoceros (Rhinoceros unicornis).$^{49}$ In searching for an ideal diluent for semen cryopreservation, many additives have been tested with the aim of fostering increased sperm viability after thawing. For example, adding detergent-active-ingredient substances (such as sodium dodecyl sulfate [SDS], or Equex) to the freezing medium improves the quality, longevity, and fertility of the sperm after thawing. ${ }^{50}$ The use of Equex for semen cryopreservation in gray wolves (Canis lupus) ${ }^{51}$ and alpacas (Vicugna pacos) ${ }^{52}$ improved sperm longevity. The addition of antioxidant substances reduces the effects of cold osmotic shock and stress due to an imbalance between the reactive oxygen species (ROS) and the antioxidants. ${ }^{53}$ In this regard, Thuwanut et al ${ }^{54}$ evaluated the impact of adding vitamin $\mathrm{E}$, Trolox (a vitamin E analog), and glutathione peroxidase (GPx) to the thawed spermatozoa of the flat-headed cat (Prionailurus planiceps) and concluded that the addition of GPx reduced oxidative stress and increased the success of cryopreservation.
In relation to CPAs, the use of egg yolk and glycerol has been studied in wild species. ${ }^{4,55-57}$ Glycerol (4\%-6\%) in the CPA allows the recovery of thawed spermatozoa in a diverse range of species including felids, ${ }^{55,58}$ marine mammals, ${ }^{59,60}$ Asian elephants (Elephas maximus) ${ }^{61,62}$ rhinos (Ceratotherium simum, C.s. cottoni), ${ }^{63}$ leopards (Neofelis nebulosa) ${ }^{64}$ bears (Ursus arctos), ${ }^{65}$ monkeys (rhesus monkeys) ${ }^{66}$ collared peccaries (Pecari tajacu), ${ }^{57}$ and many other species. Although glycerol is used for sperm cryopreservation of a wide range of species, some studies point out that there are some restrictions in its use due to its cytotoxic effects. ${ }^{67}$ Glycerol toxicity may cause protein denaturation, actin interaction and alterations, and direct disruption of the plasma membrane ${ }^{68}$ Because of this, substances such as dimethylsulfoxide (DMSO) and dimethylacetamide have been proposed as important alternatives to glycerol for semen cryopreservation in saltwater crocodiles (Crocodylus porosus) ${ }^{69}$ and kangaroos (Macropus giganteus $).^{70}$

Collection of the epididymal spermatozoa directly from the cauda of the epididymis and vas deferens is also an option for use in wild and captive animals that have high genetic value, and for animals killed accidentally. ${ }^{71}$ This method provides morphologically viable cells that retain the ability to undergo capacitation, bind to the zona pellucida, and fertilize the oocyte..$^{72,73}$ Factors such as the size of the epididymis and the diameter of the vas deferens influence the choice of technique and its success for the recovery of sperm. ${ }^{74}$ The flotation method is performed with the epididymis immersed in a buffered medium. Numerous sections in the epididymis cauda are made with a blade, followed by recumbency for some minutes. Then the sperm will migrate to the medium and can be recovered after removing the tissue pieces. ${ }^{75}$ This is the procedure of choice for small animals such as deer and squirrels, given the small size of the epididymis, ${ }^{76-78}$ but it has also been used for large animals (camels, antelopes, European bisons, and Cantabrian brown bears). ${ }^{75,79-81}$ Retrograde flushing is another method of sperm collection that involves the injection of a buffered medium inside the vas deferens using a syringe. The pressure pushes the sperm toward an incision in the cauda epididymis, generally near the junction with the corpus, where the gametes are recovered ${ }^{82}$ It allows samples to be obtained with a lower level of contamination by blood cells ${ }^{83}$ Sperm cells derived from this technique have been efficiently cryopreserved in red deer ${ }^{84}$ African buffalos, ${ }^{85}$ and agoutis. ${ }^{47}$

Cryopreservation of testicular tissues is a potential means of preserving male genetic material in endangered animals that die unexpectedly. ${ }^{86}$ This technique enables the preservation of cell integrity and the endocrine functions of 
the testes, ${ }^{87}$ allowing the preservation and posterior use of spermatozoa ${ }^{88}$ and/or spermatogonial stem cells. ${ }^{64}$ Recent developments in autografting and xenografting testes demonstrate the potential value of cryopreserving gonadal tissues. ${ }^{89,90}$ Nevertheless, a major obstacle limiting the application of this technology is the low efficiency of sperm production in many species. ${ }^{91}$

A number of CPAs have been used to protect testicular tissues against cryoinjury in order to improve the quality of spermatozoa recovered after testicle cryopreservation. Such CPAs include both penetrating and nonpenetrating CPAs such as sucrose, trehalose, glycerol, ethylene glycol (EG), 1,2-propanediol (PrOH), and DMSO. Nevertheless, the efficacy of these CPAs depends on several factors such as CPA concentration, cooling rate, and the species being studied. $^{92}$

$\mathrm{SF}$ is the conventional method used to cryopreserve testicular biopsies. Advantage is taken of the regulatory properties of extracellular ice formation to dehydrate cells during cooling and avoids toxicity to cells by exposing them to lower concentrations of CPAs while slowly decreasing the temperature. However, this method is time inefficient and requires expensive programmable freezers. ${ }^{93}$ Vitrification is another cryopreservation strategy adopted to preserve testicular biopsies. Vitrification is a fast and convenient method that involves a solidification process without crystallization that avoids the biologically damaging effects associated with ice crystal formation by using higher concentrations of CPAs and ultrafast cooling rates..$^{93,94}$

Regardless of the method used, testicular tissue cryopreservation is a promising way to preserve male germplasm and has been successfully used in domestic species (porcine, ${ }^{95}$ mouse, ${ }^{93}$ cat, ${ }^{92}$ bovine ${ }^{96}$ ), wild species (Antilope cervicapra, ${ }^{97}$ monkeys, ${ }^{98}$ Felis chaus, Panthera leo, Panthera pardus, Rusa timorensis, Muntiacus feae, Sumatran serow, Capricornis sumatraensis ${ }^{54}$ ), and human. ${ }^{99}$ Recently, Borges et $\mathrm{al}^{100}$ performed cryopreservation of testicular tissue of the collared peccary (Peccary tajacu) using a solid surface vitrification method with CPAs (EG, dimethylformamide [DMF] or DMSO, at $3 \mathrm{M}$ or $6 \mathrm{M}$ concentration). It was observed that EG preserved the nuclei and epithelium of the testicular cells.

\section{Embryos and somatic cells}

Advances in cell biotechnology have increased the interest in the creation of cell banks as sources of different cell types, but this requires knowledge of cell-type specific cryopreservation. Cryobanking of cells and tissues is an important and useful approach both for human applications and for the conservation of endangered mammalian species. ${ }^{101}$ Additionally, the cryopreservation of embryos and somatic cells offers several important logistic and economic advantages, including the preservation of embryos in excess of the number of available recipients, and national and international movement of embryos. ${ }^{102}$

Some valuable embryo biotechnologies have been developed for mustelids. Amstislavsky et al ${ }^{103}$ used SF to obtain important results in the intraspecies and interspecies embryo transfer of endangered animals. Taylor et al ${ }^{104}$ published results demonstrating the successful use of a novel microinjection system in the cryopreservation of llama embryos and confirmed pregnancy by ultrasound.

Embryos of the African lion (Panthera leo) resulting from intracytoplasmic sperm injection using frozen-thawed spermatozoa obtained by percutaneous epididymal sperm aspiration and mature oocytes were cryopreserved and subsequently transferred. ${ }^{105}$ Cryopreservation by conventional SF and vitrification in South American camelids (alpacas and llamas) yielded promising results using conventional methods. ${ }^{102,106}$ The authors found no differences in trophoblastic vesicle survival after 24 hours among control groups and those exposed to EG or propylene glycol.

Lattanzi et $\mathrm{al}^{107}$ tested the viability of llama hatched blastocysts using vitrification and SF and observed reexpansion of vitrified and slow-frozen embryos of 54\% and $57 \%$, respectively. Similarly, Von Baer and Del Campo ${ }^{108}$ tested the effect of vitrification by open pull straw (OPS) on the morphology and survival of llama hatched blastocysts and found that re-expansion of embryos after thawing was acceptable, but no pregnancies were obtained. Transmission electron microscopy (TEM) revealed a high lipid content in the cytoplasm of llama embryos and may contribute to low survival after vitrification.

Recent advances in gamete and embryo biotechnologies are demonstrating the utility of using somatic cells to obtain induced pluripotency. Induced pluripotent stem (iPS) cells derived from fibroblasts is a new approach to potentially obtain gametes from somatic cells, since iPS cells could be later differentiated into the required cell type. ${ }^{109}$ Production of iPS cells from fetal fibroblasts was first reported in the mouse. ${ }^{110}$ Concerning highly endangered species, pluripotency has also been induced in somatic cells from a primate, the drill (Mandrillus leucophaeus), from the nearly extinct white rhinoceros (Ceratotherium simum cottoni), ${ }^{111}$ as well as from the snow leopard (Panthera uncia). ${ }^{112}$ 
A pioneering study by Caamano et $\mathrm{al}^{113}$ reported that a single basic protocol can provide a method for obtaining, culturing, and cryopreserving skin fibroblasts from a wide range of wild animals. In that study, skin biopsies were taken of the brown bear (Ursus arctos), and from carcasses of accidentally killed individuals from the following species: gray wolf (Canis lupus), red fox (Vulpes vulpes), Eurasian badger (Meles meles), fallow deer (Dama dama), Pyrenean chamois (Rupicapra pyrenaica), Western roe deer (Capreolus capreolus), and wild boar (Sus scrofa). It was possible to obtain, culture, freeze, and thaw skin fibroblasts successfully from all the species studied.

Recently, León-Quinto et al ${ }^{109}$ evaluated the cryosensitivity of fetal skin cells in comparison with adult cells from the critically endangered Iberian lynx. Responses to cryoinjury were analyzed in both thawed cell types by means of cell viability and functionality, using freezing media including the permeating CPA (DMSO), either alone or along with the nonpermeating CPA sucrose. Data showed a difference between fetal and adult skin cells concerning their cryopreservation sensitivity and requirements, as well as their recovery time after thawing, with survival rates of $54 \% \pm 4 \%$ in thawed fetal cells (vs $89 \% \pm 6 \%$ for thawed adult cells).

Cryopreservation of adult cartilage cells, fetal cartilage cells, and lung tissue has produced promising results and could be very important in biodiversity conservation by biobanking. However, studies on wild animals are scarce and our knowledge is currently limited to domestic animals and marine mammals. ${ }^{114-116}$

\section{Final considerations}

Both in situ and ex situ conservation strategies can benefit from reproductive biotechniques such as artificial insemination, gamete micromanipulation, cell and tissue cryopreservation, in vitro culture, and grafting. In addition, these techniques can also be used to obtain data on the reproductive physiology of wild species. For example, in vitro culture or grafting of gonadal or somatic tissues of threatened species is a great option for their conservation. Germplasm banks can be complemented with the preservation of cell types such as embryos and blood and skin that can be used for the application of other biotechniques in order to preserve species.

There is still very little information on the physiology of wild species, and this is a problem because these data are needed for the improvement and applicability of reproductive techniques for these species. Nevertheless, the techniques reported here are very encouraging and hold great promise for the development of new methods to aid in biodiversity conservation in the future. A practical example for the use of cryopreservation to safeguard animal genetic resource is the Frozen Ark, which is supported by the Natural History Museum, the Zoological Society of London, and the Institute of Genetics at the University of Nottingham (UK); and the Global Genome Initiative (Smithsonian Institution, Washington, DC, USA). These institutions established a consortium of major zoos, aquaria, museums, and research institutions in many countries around the world, aiming to ensure genetic sources preservation.

\section{Disclosure}

The authors report no conflicts of interest in this work.

\section{References}

1. IUCN Species Survival Commission, 2010. IUCN Red List Categories and Criteria (version 3.1). Gland, Switzerland and Cambridge, UK: IUCN; 2010.

2. Andrabi SM, Maxwell WM. A review on reproductive biotechnologies for conservation of endangered mammalian species. Anim Reprod Sci. 2007;99:223-243.

3. Costa PM, Martins CF. Conservação de recursos genéticos animais através de biotécnicas de reprodução. Univ Ci Saúde. 2008;6(1): 39-55.

4. Silva AR, Souza ALP, Santos EAA, et al. Formação de bancos de germoplasma e sua contribuição para a conservação de espécies silvestres no Brasil [Formation of germplasm banks and their contribution for wild animal conservation in Brazil]. Ciência Animal. 2012;22(1):219-234. Portuguese.

5. Domingues SFS, Caldas-Bussiere MC, Martins N, Carvalho RA. Ultrasonographic imaging of the reproductive tract and surgical recovery of oocytes in Cebus apella (Capuchin monkeys). Theriogenology. 2007;68:1251-1259.

6. Lermen D, Blömeke B, Browne R, et al. Cryobanking of viable biomaterials: implementation of new strategies for conservation purposes. Mol Ecol. 2009; 18:1030-1033.

7. Santos RR, Amorim C, Cecconi S, et al. Cryopreservation of ovarian tissue: an emerging technology for female germline preservation of endangered species and breeds. Ani Reprod Sci. 2010;122:151-163.

8. Hovatta O. Methods for cryopreservation of human ovarian tissue. Reprod Biomed. 2005;10:729-734.

9. Prentice JR, Anzar M. Cryopreservation of mammalian oocyte for conservation of animal genetics. Vet Med Int. 2011;2011:1-11.

10. Tucker MJ, Morton PC, Wright G, Sweitzer CL, Massey JB. Clinical application of human egg cryopreservation. Hum Reprod. 1998;13: 3156-3159.

11. Naik BR, Rao BS, Vagdevi R, Gnanprakash M, Amarnath D, Rao VH. Conventional slow freezing, vitrification and open pulled straw (OPS) vitrification of rabbit embryos. Anim Reprod Sci. 2005;86(3-4): 329-338.

12. Amorim CA, Rondina D, Lucci CM, Gonçalves PB, Figueiredo JR, Giorgetti A. Permeability of ovine primordial follicles to different cryoprotectants. Fertil Steril. 2006;85:1077-1081.

13. Saragusty J, Arav A. Current progress in oocyte and embryo cryopreservation by slow freezing and vitrification. Reproduction. 2011;141:1-19.

14. Amorim CA, Curaba M, Van Langendonckt A, Dolmans MM, Donnez J. Vitrification as an alternative means of cryopreserving ovarian tissue. Reprod Biomed Online. 2011;23:160-186. 
15. Rodriguez-Wallberg KA, Oktay K. Recent advances in oocyte and ovarian tissue cryopreservation and transplantation. Best Pract Res Clin Obstet Gynaecol. 2012;26:391-405.

16. Mukaida T, Oka C. Vitrification of oocytes, embryos and blastocysts. Best Pract Res Clin Obstet Gynaecol. 2012;26:789-803.

17. Richings NM, Shaw G, Temple-Smith PD, Renfree MB. Growth and histology of ovarian follicles after cold storage in the tammar wallaby. Reprod Fertil Dev. 2006;18(6):677-688.

18. García-Alvarez O, Maroto-Morales A, Berlinguer F, et al. Effect of storage temperature during transport of ovaries on in vitro embryo production in Iberian red deer (Cervus elaphus hispanicus). Theriogenology. 2011;75:65-72.

19. Lima GL, Costa LL, Cavalcanti DM, et al. Short term storage of collared peccaries ovarian tissue using phosphate buffered saline (PBS) solution or powdered coconut water (ACP) based medium. Reprod Domest Anim. 2012;47:1-612.

20. Lima GL, Luz VB, Alves AMCV, et al. Vitrification of collared peccaries (Tayassu tajacu) ovarian tissue using various cryoprotectants. Anim Reprod. 2012;9(4):261.

21. Amorim CA, Jacobs S, Devireddy RV, et al. Successful vitrification and autografting of baboon (Papio anubis) ovarian tissue. Hum Reprod. 2013;28(8):2146-2156.

22. Suzuki N, Hashimoto S, Igarashi S, et al. Assessment of long-term function of heterotopic transplants of vitrified ovarian tissue in cynomolgus monkeys. Hum Reprod. 2012;27:2420-2429.

23. Schnorr J, Ochninger S, Toner J, et al. Functional studies of subcutaneous ovarian transplants in nonhuman primates: steroidogenesis, endometrial development, menstrual patterns and gamete morphology. Hum Reprod. 2002;17:612-619.

24. Lee DM, Yeoman RR, Battaglia DE, et al. Live birth after ovarian tissue transplant. Nature. 2004;428:137-138.

25. Wiedemann C, Zahmel J, Jewgenow K. Short-term culture of ovarian cortex pieces to assess the cryopreservation outcome in wild felids for genome conservation. BMC Vet Res. 2013;22:9-37.

26. Boutelle S, Lenahan K, Krisher R, Bauman KL, Asa CS, Silber S. Vitrification of oocytes from endangered Mexican gray wolves (Canis lupus baileyi). Theriogenology. 2011;75:647-654.

27. Czarny NA, Harris MS, Rodger JC. Dissociation and preservation of preantral follicles and immature oocytes from female dasyurid marsupials. Reprod Fertil Dev. 2009;21:640-648.

28. Czarny NA, Rodger JC. Vitrification as a method for genome resource banking oocytes from the endangered Tasmanian devil (Sarcophilus harrisii). Cryobiology. 2010;60:322-325.

29. Wanderley LS, Luz HK, Faustino LR, et al. Ultrastructural features of agouti (Dasyprocta aguti) preantral follicles cryopreserved using dimethyl sulfoxide, ethylene glycol and propanediol. Theriogenology. 2012;77(2):260-267.

30. Gunasena KT, Lakey JRT, Villines PM, Bush M, Raath C, Critser ES. Antral follicles develop in xenografted cryopreserved African elephant (Loxodonta africana) ovarian tissue. Anim Reprod Sci. 1998;53: 265-275.

31. Cleary M, Paris MC, Shaw J, Jenkin G, Trounson AO. Effect of ovariectomy and graft position on cryopreserved common wombat (Vombatus ursinus) ovarian tissue following xenografting to nude mice. Reprod Fertil Dev. 2003;15:333-342.

32. Cleary M, Shaw JM, Jenkin G, Trounson AO. Influence of hormone environment and donor age on cryopreserved common wombat (Vombatus ursinus) ovarian tissue xenografted into nude mice. Reprod Fertil Dev. 2004;16:699-707.

33. Wolvekamp MC, Cleary ML, Cox SL, Shaw JM, Jenkin G, Trounson AO. Follicular development in cryopreserved common wombat ovarian tissue xenografted to nude rats. Anim Reprod Sci. 2001;65:135-147.

34. Zheng YL. Recent progress in reproduction of whale oocytes. Zygote. 2013;21(3):246-249.

35. Rao BS, Mahesh YU, Suman K, et al. Meiotic maturation of vitrified immature chousingha (Tetracerus quadricornis) oocytes recovered post-mortem. Cryobiology. 2001;62:47-52.
36. Johnston LA, Lacy RC. Genome resource banking for species conservation: selection of sperm donors. Cryobiology. 1995;32:68-77.

37. Silva AR, Morato RG, Silva LDM. The potential for gamete recovery from non-domestic canids and felids. Anim Reprod Sci. 2004;81: $159-175$.

38. Watson PF. The causes of reduced fertility with cryopreserved semen. Anim Reprod Sci. 2000;61:481-492.

39. Yu I, Leibo SP. Recovery of motile, membrane-intact spermatozoa from canine epididymides stored for 8 days at $4^{\circ} \mathrm{C}$. Theriogenology. 2001;57:1179-1190.

40. Bainbridge DR, Jabbour HN. Potential of assisted breeding techniques for the conservation of endangered mammalian species in captivity: a review. Vet Rec. 1998;143:159-168.

41. Morrell JM, Nubbemeyer R, Heistermann M, et al. Artificial insemination in Callithrix jacchus using fresh or cryopreserved spermatozoa. Anim Reprod Sci. 1998;52:165-174.

42. O’Brien JK, Roth TL. Post-coital sperm recovery and cryopreservation in the Sumatran rhinoceros (Dicerorhinus sumatrensis) and application to gamete rescue in the African black rhinoceros (Diceros bicornis). J Reprod Fert. 2000;118:263-271.

43. Leibo SP, Songsasen N. Cryopreservation of gametes and embryos of nondomestic species. Theriogenology. 2002;57:303-326.

44. Comizzoli P, Wildt DE. On the horizon for fertility preservation in domestic and wild carnivores. Reprod Domest Anim. 2012;47(Suppl 6): S261-S265.

45. Li YH, Cai KJ, Kovacs A, Ji WZ. Effects of various extenders and permeating cryoprotectants on cryopreservation of Cynomolgus monkey (Macaca fascicularis) spermatozoa. J Androl. 2005;26(3):387-395.

46. Oliveira KG, Miranda SA, Leão DL, Brito AB, Santos RR, Domingues SFS. Semen coagulum liquefaction; sperm activation and cryopreservation of capuchin monkey (Cebus apella) semen in coconut water solution (CWS) and TES-TRIS. Anim Reprod Sci. 2011;123: 75-80.

47. Silva MA, Peixoto GCX, Santos EAA, Castelo TS, Oliveira MF, SilvaAR. Recovery and cryopreservation of epididymal sperm from agouti (Dasiprocta aguti) using powdered coconut water (ACP-109c) and Tris extenders. Theriogenology. 2011;76:1084-1089.

48. Imrat P, Suthanmapinanth $P$, Saikhun K, et al. Effect of pre-freeze semen quality, extender and cryoprotectant on the post-thaw quality of Asian elephant (Elephas maximus indicus) semen. Cryobiology. 2013;66:52-59.

49. Stoops MA, Atkinson MW, Blumer ES, Campbell MK, Roth TL. Semen cryopreservation in the Indian rhinoceros (Rhinoceros unicornis). Theriogenology. 2010;73:1104-1115.

50. Peña A, Lugilde LL, Barrio M, Herradón PG, Quintela LA. Effects of Equex from different sources on post-thaw survival, longevity and intracellular Ca2+ concentration of dog spermatozoa. Theriogenology. 2003;59(8):1725-1739.

51. Zindl C, Asa V, Günzel-Apel AR. Influence of cooling rates and addition of Equex pasta on cooled and frozen-thawed semen of generic gray (Canis lupus) and Mexican gray wolves (C. l. baileyi). Theriogenology. 2006;66:1797-1802.

52. Morton KM, Evans G, Maxwell WMC. Effect of glycerol concentration, Equex $\mathrm{STM}^{\circledR}$ supplementation and liquid storage prior to freezing on the motility and acrosome integrity of frozen-thawed epididymal alpaca (Vicugna pacos) sperm. Theriogenology. 2010;74:311-316.

53. Agarwal A, Saleh RA, Bedaiwy MA. Role of reactive oxygen species in the pathophysiology of human reproduction. Fertil Steril. 2003;79:829-843.

54. Thuwanut P, Srisuwatanasagul S, Wongbandue G, et al. Sperm quality and the morphology of cryopreserved testicular tissues recovered post-mortem from diverse wild species. Cryobiology. 2013;67:244-247.

55. Crosier AE, Pukazhenthi BS, Henghali JN, et al. Cryopreservation of spermatozoa from wild-born Namibian cheetahs (Acinonyx jubatus) and influence of glycerol on cryosurvival. Cryobiology. 2006;52:169-181. 
56. Garde JJ, Olmo A, Soler AJ, Espeso G, Gomendio M, Roldan ERS. Effect of egg yolk, cryoprotectant, and various sugars on semen cryopreservation in endangered Cuvier's gazelle (Gazella cuvieri). Anim Reprod Sci. 2008;108:384-401.

57. Castelo TS, Bezerra FSB, Souza ALP. Influence of the thawing rate on the cryopreservation of semen from collared peccaries (Tayassu tajacu) using Tris-based extenders. Theriogenology. 2010;74:1060-1065.

58. Stoops MA, Bond JB, Bateman HL, et al. Comparison of different sperm cryopreservation procedures on post-thaw quality and heterologous in vitro fertilisation success in the ocelot (Leopardus pardalis). Reprod Fertil Dev. 2007;19:685-694.

59. Robeck TR, Gearhart SA, Steinman KJ, Katsumata E, Loureiro JD, O'Brien JK. In vitro sperm characterization and development of a sperm cryopreservation method using directional solidification in the killer whale (Orcinus orca). Theriogenology. 2011;76:267-279.

60. Robeck TR, O'Brien JK. Effect of cryopreservation methods and precryopreservation storage on bottlenose dolphin (Tursiops truncatus) spermatozoa. Biol Reprod. 2004;70:1340-1348

61. Saragusty J, Hildebrandt TB, Behr B, Knieriem A, Kruse J, Hermes R. Successful cryopreservation of Asian elephant (Elephas maximus) spermatozoa. Anim Reprod Sci. 2009;115:255-266.

62. Thongtip N, Mahasawangkul S, Thitaram C, et al. Successful artificial insemination in the Asian elephant (Elephas maximus) using chilled and frozen - thawed semen. Reprod Biol Endocrinol. 2009;19(7):75.

63. Hermes R, Hildebrandt TB, Blottner S, et al. Reproductive soundness of captive southern and northern white rhinoceroses (Ceratotherium simum simum, C.s. cottoni): evaluation of male genital tract morphology and semen quality before and after cryopreservation. Theriogenology. 2005;63:219-238.

64. Pukazhenthi B, Comizzoli P, Travis AJ, Wildt DE. Applications of emerging technologies to the study and conservation of threatened and endangered species. Reprod Fertil Dev. 2006;18:77-190.

65. Okano T, Nakamura S, Komatsu T, et al. Characteristics of frozen-thawed spermatozoa cryopreserved with different concentrations of glycerol in Captive Japanese Black Bear (Ursus thibetanus japonicus). J Vet Med Sci. 2006;68(10):1104-1110.

66. Dong QX, Sarah ER, Dana H, Catherine AV. The role of low-density lipoprotein (LDL) and high-density lipoprotein (HDL) in comparison with whole egg yolk for sperm cryopreservation in rhesus monkeys Asian J Androl. 2011;13:459-464.

67. Holt WV. Basic aspects of frozen storage of semen. Anim Reprod Sci. 2000;62:3-22.

68. Alvarenga MA, Landim-Alvarenga FC, Moreira RM, Cesarino MM. Acrosomal ultrastructure of stallion spermatozoa cryopreserved with ethylene glycol using two packaging systems. Equine Vet J. 2000;32(6): 541-545.

69. Johnston SD, Lever J, McLeod R, et al. Extension, osmotic tolerance and cryopreservation of saltwater crocodile (Crocodylus porosus) spermatozoa. Aquaculture. 2014;426(20):213-221.

70. McClean R, Zee YP, Holt WV, Johnston SD. Cryopreservation of kangaroo spermatozoa using alternative approaches that reduce cytotoxic exposure to glycerol. Cryobiology. 2008;57(3):304-307.

71. Bezerra JAB, Silva AM, Peixoto GCX, Silva MA, Oliveira MF, Silva AR. Influence of recovery method and centrifugation on epididymal sperm from collared peccaries (Pecari tajacu Linnaeus, 1758). Zoolog Sci. 2014;31:338-342.

72. Goodrowe KL, Hay M. Characteristics and zona binding ability of fresh and cooled domestic cat epididymal spermatozoa. Theriogenology. 1993;40:967-975

73. Tsutsui T, Wada M, Anzai M, Hori T. Artificial insemination with frozen epididymal sperm in cats. J Vet Med Sci. 2003;65:397-399.

74. Chatdarong K, Thuwanut P, Morrell JM. Single-layer centrifugation through colloid selects improved quality of epididymal cat sperm. Theriogenology. 2010;73(1284):1292.

75. Anel L, Alvarez M, Anel E, et al. Evaluation of three different extenders for use in emergency salvaging of epididymal spermatozoa from a cantabric brown bear. Reprod Domest Anim . 2011;46:85-90.
76. Martinez-Pastor F, Corujo ARD, Anel E, Herraez P, Paz P, Anel L. Post mortem time and season alter subpopulation characteristics of Iberian red deer epididymal sperm. Theriogenology. 2005;64:958-974.

77. Martinez-Pastor F, Guerra C, Kaabi M, et al. Decay of sperm obtained from epididymes of wild ruminants depending on post-mortem time. Theriogenology. 2005;63:24-40.

78. Ping S, Wang F, Zhang F, et al. Cryopreservation of epididymal sperm in tree shrews (Tupaia belangeri). Theriogenology. 2011;76:39-46.

79. Waheed MM, Al-Eknah MM, El-Bahr MM. Some biochemical characteristics and preservation of epididymal camel spermatozoa (Camelus dromedarius). Theriogenology. 2011;76:1126-1133.

80. Saragusty J, Gacitua H, King R, Arav A. Post-mortem semen cryopreservation and characterization in two different endangered gazelle species (Gazella gazella and Gazella dorcas) and one subspecies (Gazella gazelle acaiae). Theriogenology. 2006;66:775-784.

81. Kozdrowski R, Nizanski W, Dubiel A, Olech W. Possibilities of using the European bison (Bison bonasus) epididymal spermatozoa collected post-mortem for cryopreservation and artificial insemination: a pilot study. Reprod Biol Endocrinol. 2011;8:9-31.

82. Garde J, Aguado M, Pérez S, Garrido D, Pérez-Guzmán M, Montoro V. Physiological characteristics of epididymal spermatozoa from postmortem rams. Theriogenology. 1994;41:203.

83. Martinez-Pastor F, Garcia-Macias V, Alvarez M, et al. Comparison of two methods for obtaining spermatozoa from the cauda epididymis of Iberian red deer. Theriogenology. 2006;65:471-485.

84. Comizzoli P, Mermillod P, Cognie Y, Chai N, Legendre X, Mauge R. Successful in vitro production of embryos in the red deer (Cervus elaphus) and the sika deer (Cervus nippon). Theriogenology. 2001;55: 649-659.

85. Herold FC, Aurich JE, Gerber D. Epididymal sperm from the African buffalo (Syncerus caffer) can be frozen successfully with AndroMed ${ }^{\mathbb{R}}$ and with Triladyl ${ }^{\mathrm{TM}}$ but the addition of seminal plasma is detrimental. Theriogenology. 2004;61(715):724.

86. Tharasanit T, Buarpung S, Manee-In T, et al. Birth of kittens after the transfer of frozen-thawed embryos produced by intracytoplasmic sperm injection with spermatozoa collected from cryopreserved testicular tissue. Reprod Domest Anim. 2012;47(Suppl 6):S305-S308.

87. Yildiz C, Mullen B, Jarvi K, McKerlie C, Lo KC. Effect of different cryoprotectant agents on spermatogenesis efficiency in cryopreserved and grafted neonatal mouse testicular tissue. Cryobiology. 2013;67: 70-75.

88. Devi L, Makala H, Pothana L, Nirmalkar K, Goel S. Comparative efficacies of six different media for cryopreservation of immature buffalo (Bubalus bubalis) calf testis. Reprod Fertil Dev. Epub 2014 Dec 8.

89. Oktay KH, Yih M. Preliminary experience with orthotopic and heterotopic transplantation of ovarian cortical strips. Sem Reprod Med. 2002;20:63-74.

90. Tibary A, Anouassi A, Khatir H. Update on reproductive biotechnologies in small ruminants and camelids. Theriogenology. 2005;64:618-638.

91. Paris CJM, Snow M, Cox SL, Shaw JM. Xenotransplantation: a tool for reproductive biology and animal conservation. Theriogenology. 2004;61:277-291.

92. Buarpung S, Tharasanit T, Comizzoli P, Techakumphu M. Feline spermatozoa from fresh and cryopreserved testicular tissues have comparable ability to fertilize matured oocytes and sustain the embryo development after intracytoplasmic sperm injection. Theriogenology. 2013;79:149-158.

93. Baert Y, Goossens E, van Saen D, Ning L, in't Veld P, Tournaye H. Orthotopic grafting of cryopreserved prepubertal testicular tissue: in search of a simple yet effective cryopreservation protocol. Fertil Steril. 2012;97(5):1152-1157.

94. Curaba M, Verleysen M, Amorim CA, et al. Cryopreservation of prepubertal mouse testicular tissue by vitrification. Fertil Steril. 2011;95: 1229-1234.

95. Abrishami M, Anzar M, Yang Y, Honaramooz A. Cryopreservation of immature porcine testis tissue to maintain its developmental potential after xenografting into recipient mice. Theriogenology. 2010;73: 86-96. 
96. Peng Z, Peng-fei H, Ya-guang T, He H, Gui-xue Z. Isolation, purification and cryopreservation of cells from neonatal bovine testis. J Northeast Agric Univ (Engl Ed). 2013;20(1):37-42.

97. Goel S, Reddy N, Mahla RS, Suman SK, Pawar RM. Spermatogonial stem cells in the testis of an endangered bovid: Indian black buck (Antilope cervicapra L.). Anim Reprod Sci. 2011;126:251-257.

98. Schlatt S, von Schönfeldt V, Nieschlag E. Germ cell transplantation in the male: animal studies with a human perspective. Hum Fertil. 1999;2:143-148.

99. Jahnukainen K, Ehmcke J, Hou M, Schlatt S. Testicular function and fertility preservation in male cancer patients. Best Pract Res Clin Endocrinol Metab. 2011;25:287-302.

100. Borges PAC, Lima GL, Bezerra JAB, et al. Cryopreservation of testicular tissue: a potential tool for the conservation of male genetic material from collared peccaries (Pecari tajacu). Anim Reprod. 2014;12(1): 272.

101. Agca Y. Genome resource banking of biomedically important laboratory animals. Theriogenology. 2012;78:1653-1665.

102. Sumar JB. Embryo transfer in domestic South American camelids. Anim Reprod Sci. 2013;136:170-177.

103. Amstislavsky S, Lindeberg H, Aalto J, et al. Embryo cryopreservation and transfer in Mustelidae: approaches to ex situ conservation of the endangered European mink. Int J Refrig. 2006;29:396-402.

104. Taylor P, Taylor S, Sansinena M, Godke R. Llama (Lama glama) pregnancies from vitrified/warmed blastocysts using a novel coaxial cryoprotectant microinjection system. Rep Fert Dev. 2006;18(1\&2): 164.

105. Damiani P, Gomez M, Cole A, et al. The production of intracytoplasmic sperm injection lion (Panthera Leo) embryos using spermatozoa collected by percutaneous epididymal sperm aspiration from vasectomized males. Rep Fert Dev. 2004;16(2):223-224.

106. Palasz AT, Adams G, Brogliatti G, Mapletoft R. Effect of day of collection and of permeating cryoprotectants on llama (Lama glama) embryos and trophoblastic vesicles. Theriogenology. 2000; 53(1):341
107. Lattanzi M, Santos C, Chaves G, et al. Cryopreservation of llama (Lama glama) embryos by slow freezing and vitrification [abstract]. Theriogenology. 2002;57:585.

108. Von Baer A, Del Campo M. Vitrification and cold storage of llama (Lama glama) hatched blastocysts [abstract]. Theriogenology. 2002;57:489.

109. León-Quinto T, Simón MA, Cadenas R, Martínez A, Serna A. Different cryopreservation requirements in foetal versus adult skin cells from an endangered mammal, the Iberian lynx (Lynx pardinus). Cryobiology. 2014;68:227-233.

110. Takahashi K, Yamanaka S. Induction of pluripotent stem cells from mouse embryonic and adult fibroblast cultures by defined factors. Cell. 2006;126:663-676.

111. Ben-Nun IF, Montague SC, Houck ML, et al. Induced pluripotent stem cells from highly endangered species. Nat Methods. 2011;8: 829-836.

112. Verma R, Holland MK, Temple-Smith P, Verma PJ. Inducing pluripotency in somatic cells from the snow leopard (Panthera uncia), an endangered felid. Theriogenology. 2012;77:220-228.

113. Caamano JN, Hermsen M, Marcos J, et al. A procedure to obtain fibroblasts from wild animals. Rep Fert Dev. 2005;17(1\&2):245.

114. Cetinkaya G, Arat S. Cryopreservation of cartilage cell and tissue for biobanking. Cryobiology. 2011;63:292-297.

115. Mancia A, Spyropoulos DD, McFee WE, Newton DA, Baatz JE. Cryopreservation and in vitro culture of primary cell types from lung tissue of a stranded pygmy sperm whale (Kogia breviceps). Comp Biochem Physiol C Toxicol Pharmacol. 2012;155(pt C):136-142.

116. Abazari A, Jomba NM, Elliott JAW, McGann LE. Cryopreservation of articular cartilage. Cryobiology. 2013;66:201-209.
Research and Reports in Biodiversity Studies

\section{Publish your work in this journal}

Research and Reports in Biodiversity Studies is an international, peerreviewed, open access journal publishing original research, reports, reviews and commentaries on all areas of biodiversity research. The manuscript management system is completely online and includes a

\section{Dovepress}

very quick and fair peer-review system. Visit http://www.dovepress.com/ testimonials.php to read real quotes from published authors. 